\title{
Inhibition Behavior of PCDD/Fs Congeners by Addition of N-containing Compound in the Iron Ore Sintering
}

\author{
Yifan Wang ${ }^{1}$, Lixin Qian ${ }^{1}$, Zhengwei Yu ${ }^{1 *}$, Tiejun Chun ${ }^{1 *}$, Hongming Long ${ }^{1,2}$, Xuejian Wu ${ }^{1}$, \\ Jiaxin $\mathbf{L i}^{1}$ \\ ${ }^{1}$ School of Metallurgical Engineering, Anhui University of Technology, Ma'anshan, Anhui 243002, China \\ ${ }^{2}$ Anhui Province Key Laboratory of Metallurgy Engineering \& Resources Recycling, Anhui University of Technology, \\ Ma'anshan 243002, China
}

\begin{abstract}
PCDD/Fs are typical toxic persistent aromatic compounds that greatly reduce air quality and harm human health. In this study, urea's suppressive effect on PCDD/Fs and their congener emissions was investigated via sintering pot tests, and the inhibition mechanisms were studied. The results showed that the I-TEQ values for the total PCDD/Fs decreased from 0.50 to $0.20,0.12$ and $0.20 \mathrm{ng}$ I-TEQ $\mathrm{Nm}^{-3}$ after adding solid $0.02,0.035$ and $0.05 \mathrm{wt} \%$ urea particles, respectively, to the iron ore sintering mixture, but these values increased for the low-chlorinated TeCDFs (from 0.003 to $0.009,0.006$ and 0.006 ng I-TEQ Nm${ }^{-3}$ ) and TeCDDs (from 0.014 to $0.020,0.018$ and $0.020 \mathrm{ng} \mathrm{I-TEQ} \mathrm{Nm}^{-3}$ ). Moreover, the average I-TEQ values for the chlorine substituents in the PCDFs and PCDDs decreased, indicating that urea inhibited chlorination or enhanced dechlorination. The potential mechanisms by which urea suppresses the total PCDD/Fs and hydrodechlorinates the highchlorinated PCDD/Fs are discussed.
\end{abstract}

Keywords: PCDD/Fs; Congeners; Urea; Active radical; Iron ore sintering.

\section{INTRODUCTION}

In 1977, Dutch scientists first detected the presence of dioxins in the exhaust gas and fly ash of waste incineration, which aroused widespread concern and in-depth research in the environmental field (Kasai et al., 2008). Dioxins are typical toxic persistent aromatic compounds, including polychlorinated dibenzo- $p$-dioxins (PCDDs) and polychlorinated dibenzofurans (PCDFs), also referred to as "PCDD/Fs" (Dvořák et al., 2010; Yabar et al., 2013; Liao et al., 2016; Zhan et al., 2019). PCDD/Fs are highly toxic that can cause reproductive and developmental problems, damage the immune system, interfere with hormones, and induce cancer as well (Shen et al., 2018). Studies have shown that the average concentrations of PCDD/Fs in the air of some cities in China were between 0.036 and 0.060 pg I-TEQ $\mathrm{Nm}^{-3}$ (Tang et al., 2017; Xing et al., 2017). Owing to the great harm of PCDD/Fs to the ecological environment, air quality, and human health, PCDD/Fs have been included into the Annex C compounds of the Stockholm Convention ( $\mathrm{Yu}$ et

\footnotetext{
* Corresponding authors.

E-mail address: yuzhengw@ahut.edu.cn (Z. Yu); springcsu@126.com (T. Chun)
}

al., 2016; Li et al., 2018; Xu et al., 2019). Previous studies generally concluded that the formations of PCDD/Fs are a heterogeneous reaction $\left(200-500^{\circ} \mathrm{C}\right)$ and a homogeneous reaction $\left(500-800^{\circ} \mathrm{C}\right)$ (Chen et al., 2018). Furthermore, three general formation pathways were proposed as follow: (i) de novo synthesis by catalytic metals ( $\mathrm{Cu} / \mathrm{Fe}$ ); (ii) precursor pathway; (iii) the rearrangement reactions of chlorophenols and chlorobenzenes (Harjanto et al., 2002; Zhang et al., 2016; Xuan et al., 2017; Chen et al., 2019; Ma et al., 2019). So far, municipal waste incineration, iron ore sintering industry, electric steelmaking industry, non-ferrous metal recycling industry, cement production industry, etc. are the potential sources of PCDD/Fs emission (Kuo et al., 2011; Yang et al., 2019).

Among them, iron ore sintering is an essential process in the long steelmaking process and the primary emission source of pollutants as well (Chen et al., 2016; Chun et al., 2017; Rezvanipour et al., 2018). The process of the iron ore sintering is presented in Fig. 1. As shown in this figure, first of all, the raw materials including iron ores, fuels, fluxes, solid waste, recirculated material, etc. are mixed and pelletized with water, then placed on a slow-moving bed to sinter into a lump at temperatures over $1300^{\circ} \mathrm{C}$ (Thompson et al., 2016; Kumar et al., 2018). Utilizing a high-power draft fan to draw the exhaust gas from the sintering bed, then the exhaust gas passes through a series of wind boxes and enters an electrostatic 


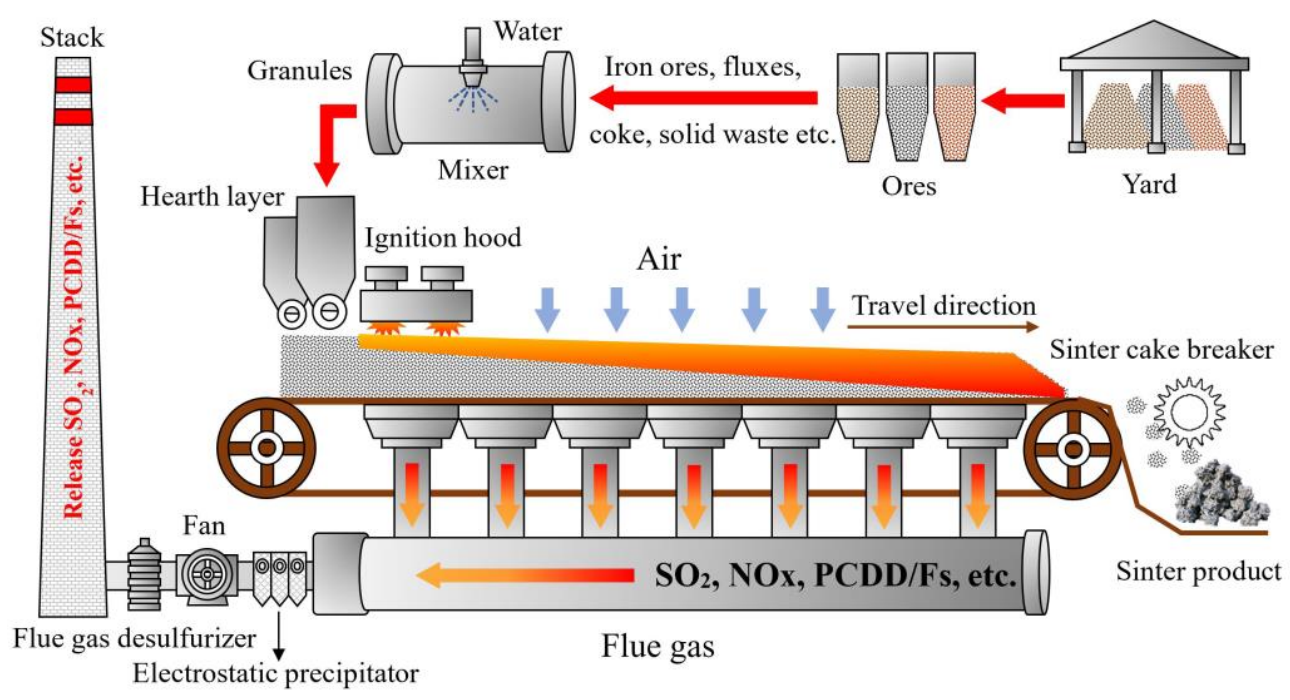

Fig. 1. Schematic diagram of the iron ore sintering process.

precipitator for dust removal. Afterward, the exhaust gas is desulfurized and released via a stack (Ooi et al., 2008a; Abreu et al., 2015; Ji et al., 2017). Meanwhile, the pollutants, like $\mathrm{NO}_{\mathrm{x}}, \mathrm{PCDD} / \mathrm{Fs}$, etc., are released into the atmosphere as well.

Previous studies showed that PCDD/Fs formed in the sintering process exhibited typical characteristics of de novo synthesis (Drage et al., 2014; Liu et al., 2017; Yang et al., 2017). PCDD/Fs can be generated in the drying zone, where the temperature between 200 and $650^{\circ} \mathrm{C}$, a large amount of carbon source, chlorides and catalytic metal $\left(\mathrm{Cu}^{+} / \mathrm{Fe}^{+}\right)$are essential for the de novo synthesis (Nakano et al., 2005). According to the formation mechanism of PCDD/Fs in the sintering process, injection inhibitors have been extensively studied and confirmed to be an effective method to control the formation of PCDD/Fs (Yan et al., 2014). At present, there are three types of inhibitors, i.e., nitrogen (N)-containing inhibitors, S-containing inhibitors, and alkaline inhibitors. However, due to the negative effect on $\mathrm{SO}_{2}$ emission levels in the flue gas and quality of sinter, S-containing and alkaline inhibitors were restricted in utilization during the sintering process (Qian et al., 2018). The N-containing inhibitors, especially urea, added in sintering raw mixture have no negative impact on the production process and product quality. Hence, it was widely used to reduce the emission of PCDD/Fs during the iron ore sintering (Nakano et al., 2005). Several studies reported that the addition of 0.02-0.05 wt.\% urea into the iron ore sintering mixtures could reduce the emission of PCDD/Fs by about 50-65\% (Southern et al., 2000; Xhrouet and Pauw, 2005; Anderson et al., 2007; Ooi et al., 2008b). Furthermore, in our previous studies, we also indicated that the PCDD/Fs emission reduction rate was $72.1 \%$ after adding $0.5 \mathrm{wt} . \%$ urea aqueous solution into the sintering mixtures in sintering pot tests (Long et al., 2011).

Similarly, experiments to reduce exhaust gas pollutant emission in municipal solid waste incineration showed that adding a certain amount of urea could achieve PCDD/Fs emission reduction (Peng et al., 2016; Ma et al., 2018). A previous study in a full-scale municipal solid waste incinerator indicated that urea concentration in the splayed water was set at 0.1 wt.\% with a splaying rate of $2000 \mathrm{~kg} \mathrm{~h}^{-1}$, the international toxic equivalent (I-TEQ) value of the PCDD/Fs in the flue gas was reduced by about $50 \%$ (Kasai et al., 2008). Ruokojärvi et al. (2001) also reported that total PCDD/Fs concentration decreased by a maximum of $74 \%$ when $1 \mathrm{wt} . \%$ of the fuel input of urea was injected into the flue gas in a pilot-scale plant. Moreover, Ruokojärvi et al. (2001) discovered that the emission ratios of low-chlorinated TeCDD and TeCDF were increased by $34 \%$ and $52 \%$, respectively, when $0.1 \mathrm{wt} . \%$ urea was added in the flue gas of municipal solid waste incineration.

In view of the above, the present papers showed that the addition of urea within the formation temperature range of $\mathrm{PCDD} / \mathrm{Fs}$ can reduce the total $\mathrm{PCDD} / \mathrm{Fs}$ emissions in municipal solid waste incineration and urea has a different suppression efficiency on PCDD/Fs congeners. However, most studies focused on the total PCDD/Fs emissions after the addition of urea during the iron ore sintering, the different inhibitory behavior of urea on PCDD/Fs congeners and the differential inhibition mechanism of PCDD/Fs was still unclear. To fill the current knowledge gap, in this study, the suppression effect of the addition of urea into the sintering mixture on PCDD/Fs emission was analyzed. The influence of urea on the suppression efficiency differences of PCDD/Fs congeners was investigated. Finally, the studies allowed demonstrating the dechlorination mechanism of urea on PCDD/Fs molecules.

\section{MATERIAL AND METHODS}

\section{Materials}

In this study, a commercial sintering plant (located in Jiangsu Province, China) provided the raw materials for the sintering pot tests. The main chemical compositions and the added mass ratio of the raw materials were shown in Table 1. The ferrous materials were the iron ore fines (including Cara ore, Pilbara blend ore, Yankee ore, SFHT ore and Meishan concentrate) and recycling materials (blast furnace dust and miscellaneous ore or other by-products). Fluxes included 
Table 1. Chemical compositions and the mass ratio of all raw materials (mass fraction, \%).

\begin{tabular}{lllllllll}
\hline Raw material & $\mathrm{TFe}^{*}$ & $\mathrm{SiO}_{2}$ & $\mathrm{CaO}$ & $\mathrm{MgO}$ & $\mathrm{Al}_{2} \mathrm{O}_{3}$ & $\mathrm{P}_{2} \mathrm{O}_{5}$ & $\mathrm{C}$ & $\mathrm{Mass}$ ratio \\
\hline Pilbara blend ore & 62.10 & 3.45 & 0.08 & 0.10 & 2.33 & 0.23 & - & 13.04 \\
Yankee ore & 58.84 & 4.64 & 0.09 & 0.12 & 1.58 & 0.11 & - & 14.30 \\
SFHT ore & 59.74 & 11.06 & 0.09 & 0.17 & 1.20 & 0.11 & - & 3.15 \\
Cara ore & 66.27 & 2.05 & 0.11 & 0.12 & 1.41 & 0.09 & - & 15.56 \\
Meishan concentrate & 56.10 & 4.84 & 3.48 & 1.21 & 0.95 & 0.27 & - & 9.68 \\
Return fines & 56.80 & 5.30 & 10.12 & 1.77 & 1.80 & 0.18 & - & 27.81 \\
Blast furnace dust & 38.48 & 7.46 & 2.74 & 1.34 & 2.98 & 0.14 & 30.63 & 1.61 \\
Mixed ore & 47.65 & 4.22 & 13.22 & 2.47 & 1.16 & 0.48 & 11.78 & 3.19 \\
Dolomite & 0.35 & 3.37 & 30.80 & 19.60 & 0.68 & 0.23 & - & 3.84 \\
Limestone & 2.91 & 3.10 & 53.10 & 0.30 & 0.64 & 0.02 & - & 0.96 \\
Lime & 0.51 & 3.76 & 82.00 & 0.84 & 1.81 & 0.02 & - & 3.23 \\
Coke fines & 1.07 & 5.49 & 0.78 & 0.15 & 4.10 & 0.07 & 88.20 & 3.63 \\
\hline
\end{tabular}

* The total $\mathrm{Fe}$ in the raw material; $\mathrm{C}$ is the fixed carbon.

limestone, dolomite, and active lime. Fuel was the coke fine. The binary basicity $\left(w(\mathrm{CaO}) / w\left(\mathrm{SiO}_{2}\right)\right)$ and coke fine content were fixed at 1.90 and $3.63 \mathrm{wt} . \%$, respectively. Industrial solid urea (containing 46.7 wt.\% nitrogen) was used as an inhibitor in the experiments, and its average particle size was 1-2 $\mathrm{mm}$. The solid urea particle was directly added into the mixing process at the rates of $0.020,0.035$ and $0.050 \mathrm{wt} . \%$ of the total sintering mixtures.

\section{Methods}

\section{Sintering Pot Tests}

The sintering pot tests were carried out to simulate a commercial sintering process. Sintering pot process included proportioning, mixing, granulation, charging, ignition, sintering, cooling and PCDD/Fs detection, as shown in Fig. 2. During the mixing, the solid urea was injected into the sintering mixtures according to the set mass proportion and mixed evenly. Next, the mixtures were granulated to large particles with the addition of water. After the granulation process completed, $3 \mathrm{~kg}$ sinter particles with the diameter of $10-16 \mathrm{~mm}$ were added into the bottom of the sintering pot as hearth layer, and then approximately $98 \mathrm{~kg}$ sintering mixtures with the moisture of $6.8 \pm 0.2 \%$ were charged into a sintering pot with the height of $720 \mathrm{~mm}$ and the diameter of $300 \mathrm{~mm}$. After charging, the mixtures in the sintering pot were ignited by a liquefied gas burner for 2 min with draft fan negative pressure of $7 \mathrm{kPa}$ at the temperature of $1100 \pm 50^{\circ} \mathrm{C}$. Simultaneously, PCDD/Fs testing devices were conducted. The igniter was moved away after ignition completing, the negative pressure of the draft fan was raised to $14 \mathrm{kPa}$ and the temperature of the flue gas at the bottom of the grate was measured during the sintering and maintained till the end of the sintering process. When the temperature of the flue gas reached its maximum value, $\mathrm{PCDD} /$ Fs testing devices were closed and the sintering pot test ended (Jiang et al., 2015; Cheng et al., 2017). Compared with the commercial sintering process, the sintering pot test was a discontinuous process and one sintering time was about $30 \mathrm{~min}$. The collection time of PCDD/Fs for one sample was $1 \mathrm{~h}$. Therefore, to ensure reproducibility, four identical sintering pot tests were done for each group of samples and the sampling of PCDD/Fs lasts for $2 \mathrm{~h}$ ( $1 \mathrm{~h}$ for one sample).

\section{Mechanism for Sampling}

In this experiment, PCDD/Fs sampling device for flue gas in the iron ore sintering process adopted the instrument recommended in HJ 77.2-2008 and the specific method for taking samples from the sintering process refers to the previous research (Qian et al., 2016). The sampling and analysis of PCDD/Fs samples were completed by the Centre Testing International Group Co., Ltd. (CTI). The CTI was a laboratory accredited by the China National Accreditation Service for Conformity Assessment (CNAS) and has the China Metrology Accreditation (CMA) qualification. The sampling device mainly included a sampling tube, gas adsorption unit, filter membranes, condensing device, flow measurement, control device, etc. The specific introduction could refer to our previous study (Long et al., 2011).

Using adsorption materials and filter membranes to collect the PCDD/Fs, including gas-, solid- and liquid-phase samples. In addition, four sampling internal standard substances $\left({ }^{13} \mathrm{C}-123478-\mathrm{HxCDD},{ }^{13} \mathrm{C}-23478-\mathrm{PeCDF},{ }^{13} \mathrm{C}\right.$ 123478-HxCDF, and ${ }^{13} \mathrm{C}-1234789-\mathrm{HpCDF}$ ) were added before sampling and the recovery rate of the internal standard substances was required to be $70-130 \%$, otherwise, the sample needed to be resampled.

\section{Analysis Method}

The collected PCDD/Fs were transported to the dioxin test laboratory under dark for analysis after each sintering pot test. Before sample extraction, several purified internal standard substances, like ${ }^{13} \mathrm{C}-2378-\mathrm{TCDF},{ }^{13} \mathrm{C}-12378-\mathrm{PeCDF}$, etc., were added into the sample. The mean recoveries of internal standard substances were required to be $40-130 \%$. For each collected sample, first of all, it was pre-treated with toluene extraction, concentrated to $3 \mathrm{~mL}$ by using a rotary evaporator (Eyela, Tokyo, Japan) and then purified with a multilayer silica gel, which was composed of acid, alkali, and neutral silica gel. Finally, the purified extract was condensed to $20 \mu \mathrm{L}$ by a nitrogen blower, and then further condensed to near-dryness with using a nitrogen stream, readied for analysis. PCDD/F detection congeners adopted isotope dilution high-resolution gas chromatography/highresolution mass spectrometry, using a 6890 Series Gas Chromatograph (Hewlett-Packard, USA), coupled to an 


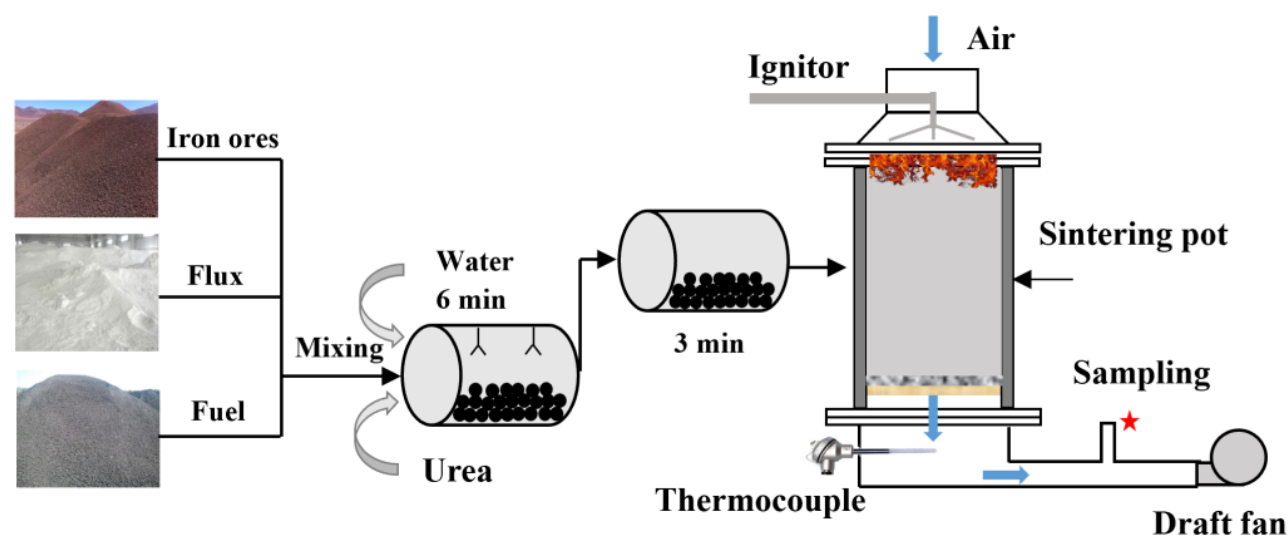

Fig.2. Schematic diagram of the sinter pot experiment.

AutoSpec Premier (Waters, USA). Besides, a DB-5 quartz capillary column was used to carry out the chromatographic separations. Injections were done using the splitless mode with a column oven temperature program. The temperature could be adjusted between $50-350^{\circ} \mathrm{C}$. The initial temperature

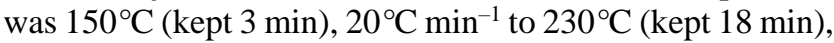
$5^{\circ} \mathrm{C} \mathrm{min}{ }^{-1}$ to $235^{\circ} \mathrm{C}$ (kept $10 \mathrm{~min}$ ), then $4^{\circ} \mathrm{C} \mathrm{min}^{-1}$ to $330^{\circ} \mathrm{C}$ (kept $3 \mathrm{~min})$. The carrier gas was the helium $(99.999 \%$ purity) (Xhrouet et al., 2001; Kuo et al., 2012; Wu et al., 2016). The I-TEQ values were calculated using I-TEF WHO-05 $_{2}$ (Van den Berg et al., 2006).

\section{Statistical Methods}

The emission concentration of PCDD/Fs calculated in this paper was the arithmetic mean value of two parallel samples for each group of samples.

The removal rate $(\delta)$ of PCDD/Fs was calculated through Eq. (1):

$$
\delta=\frac{C 1-C 2}{C 1} \times 100 \%
$$

where $\mathrm{C} 1$ is the $\mathrm{PCDD} / \mathrm{Fs}$ concentration without urea (ng ITEQ $\mathrm{Nm}^{-3}$ ); $\mathrm{C} 2$ is the $\mathrm{PCDD} / \mathrm{Fs}$ concentration with urea (ng I-TEQ $\mathrm{Nm}^{-3}$ ).

The chlorination degree of PCDD/Fs $\left(q_{c}\right.$, average I-TEQ number of chlorine atom) was calculated according to Eq. (2):

$q_{c}=\sum_{i=4}^{8} w_{i} \times n_{i}$

where $w_{i}$ is the I-TEQ weight percentage of PCDDs and PCDFs; $n_{i}$ is the number of the chlorine atom.

\section{RESULTS AND DISCUSSION}

\section{Concentrations of PCDD/Fs}

For all experiment samples, the recovery rates of sampling internal standard substances were $87.1-102.4 \%$ (non-urea), 96.7-106.0\% (0.02\% urea), 96.3-105.0\% (0.035\% urea), $76.8-88.5 \%$ (0.05\% urea) within $70-130 \%$. The internal standard substance recovery rates of all samples after purification were in the range of $40-130 \%$. The results of the analysis showed that the samples were not significantly contaminated.

The effect of urea addition on PCDD/Fs emission concentration and the detection results of 17 targeted PCDD/Fs congeners were analyzed according to the accumulation of international toxic equivalency factors (I-TEFs), as listed in Table 2. The I-TEQ value without urea was $0.5 \mathrm{ng} \mathrm{I}^{-T E Q ~} \mathrm{Nm}^{-3}$. After $0.020,0.035$ and 0.050 wt. $\%$ urea added into the sintering mixtures, the emission of I-TEQ values reduced to $0.20,0.12$ and $0.20 \mathrm{ng}$ I-TEQ $\mathrm{Nm}^{-3}$ respectively, and the reduction efficiencies were 60.0, 76.0 and 60.0\%, separately, which was similar to the results of previous studies (Anderson et al., 2007; Ooi et al., 2008a). The results showed that urea has an obvious inhibitory effect on the emission of $\mathrm{PCDD} / \mathrm{Fs}$, which further proves that the addition of urea in mixtures can reduce the FCDD/Fs emission during the iron ore sintering.

\section{Different Inhibition of PCDFs and PCDDs}

The emission I-TEQ values of PCDFs and PCDDs were presented in Fig. 3(a). In the case of non-urea, the value of PCDFs and PCDDs were 0.380 and $0.120 \mathrm{ng}$ I-TEQ $\mathrm{Nm}^{-3}$, the ratio of PCDFs/PCDDs was 3.15, which was a typical emission distribution of $\mathrm{PCDD} / \mathrm{Fs}$ during the iron ore sintering process (Xhrouet and Pauw, 2005). Previous studies showed that the formation of PCDFs congeners was dominated by de novo synthesis (Huang and Buekens, 1995; Chen et al., 2019) and most PCDDs were synthesized through the precursor pathway (Weber and Hagenmaier, 1999). Therefore, the de novo synthesis was the primary formation route of PCDD/Fs during the iron ore sintering process.

With addition of $0.020,0.035$ and 0.050 wt.\% urea into the iron ore sinter mixtures, the emission of I-TEQ values were $0.167,0.098,0.131 \mathrm{ng}$ I-TEQ $\mathrm{Nm}^{-3}$ for PCDFs and 0.037, 0.027, $0.067 \mathrm{ng}$ I-TEQ Nm${ }^{-3}$ for PCDDs, separately. The PCDFs/PCDDs-ratios became 4.45, 3.68 and 1.95, respectively. Fig. 3(b) presented the inhibition efficiency of PCDFs and PCDDs calculated in different experiments. As illustrated in this figure, the reduction ratios of PCDFs (PCDDs) increased from $56.2 \%$ to $74.3 \%$ (from $68.9 \%$ to $78.0 \%$ ) with augmenting urea ratio from $0.020 \%$ to $0.035 \%$. The inhibition effect of PCDDs was more obvious than that 
Table 2. Analyzing results of PCDD/Fs (ng I-TEQ Nm${ }^{-3}$ ).

\begin{tabular}{|c|c|c|c|c|c|}
\hline \multirow{2}{*}{ Classification } & \multirow{2}{*}{ Congener } & \multicolumn{4}{|c|}{ I-TEQ* } \\
\hline & & Non-urea & $0.02 \%$ urea & $0.035 \%$ urea & $0.05 \%$ urea \\
\hline \multirow[t]{10}{*}{ PCDFs } & 2378-TeCDF & 0.0034 & 0.009 & 0.006 & 0.0064 \\
\hline & 12378-PeCDF & 0.0055 & 0.006 & 0.004 & 0.0045 \\
\hline & 23478-PeCDF & 0.17 & 0.085 & 0.06 & 0.07 \\
\hline & 123478-HxCDF & 0.039 & 0.018 & 0.0097 & 0.011 \\
\hline & 123678-HxCDF & 0.049 & 0.022 & 0.011 & 0.013 \\
\hline & 234678-HxCDF & 0.068 & 0.017 & 0.012 & 0.016 \\
\hline & 123789-HxCDF & 0.023 & 0.003 & 0.0026 & 0.0045 \\
\hline & 1234678-HpCDF & 0.019 & 0.0059 & 0.0032 & 0.0043 \\
\hline & 1234789-HpCDF & 0.0025 & 0.0006 & 0.00051 & 0.00065 \\
\hline & OCDF & 0.00082 & 0.00016 & 0.00017 & 0.00018 \\
\hline \multirow[t]{7}{*}{ PCDDs } & 2378-TeCDD & 0.014 & 0.02 & 0.005 & 0.02 \\
\hline & 12378-PeCDD & 0.045 & 0.01 & 0.005 & 0.02 \\
\hline & 123478-HxCDD & 0.014 & 0.0015 & 0.0009 & 0.0042 \\
\hline & 123678-HxCDD & 0.021 & 0.002 & 0.0005 & 0.01 \\
\hline & 123789-HxCDD & 0.013 & 0.0015 & 0.0016 & 0.0066 \\
\hline & 1234678-HpCDD & 0.012 & 0.0021 & 0.00088 & 0.0054 \\
\hline & OCDD & 0.0016 & 0.00036 & 0.00016 & 0.00079 \\
\hline Total PCDD/Fs (PCDDs + PCDFs) & - & 0.50 & 0.20 & 0.12 & 0.20 \\
\hline I-TEQ inhibition & - & $0 \%$ & $60.0 \%$ & $76.0 \%$ & $60.0 \%$ \\
\hline $\mathrm{q}_{\mathrm{c}}-\mathrm{PCDFs}$ & - & 5.58 & 5.39 & 5.35 & 5.37 \\
\hline $\mathrm{q}_{\mathrm{c}}$-PCDDs & - & 5.52 & 4.72 & 4.5 & 5.21 \\
\hline
\end{tabular}

* International toxic equivalent, which is calculated by multiplying the measured value of the concentration of each PCDD/Fs congener by the international toxic equivalency factor (I-TEF) and then adding them up.
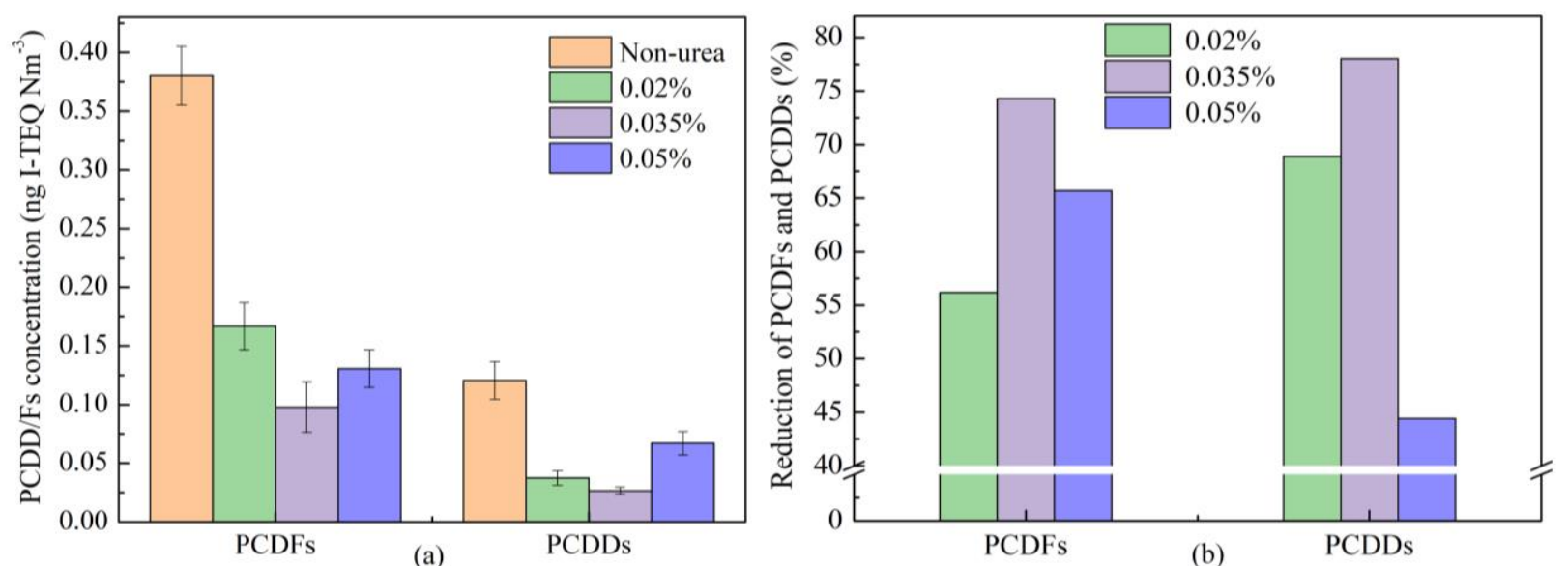

Fig. 3. Emission value and suppression efficiency of PCDD/Fs: (a) emission of I-TEQ values of PCDDs and PCDFs; (b) suppression efficiency of PCDDs and PCDFs.

of PCDFs. However, when the addition ratio of urea increased to $0.050 \%$, the reduction efficiency of PCDFs (PCDDs) reduced to $65.7 \%(44.5 \%)$, and the inhibition effect of PCDFs was more obvious than that of PCDDs. This phenomenon can be explained by two reasons: (i) When the proportion of urea added is low $(0.020$ and $0.035 \%)$, urea preferentially inhibits PCDD/Fs formation of dioxins precursors, like chlorobenzenes, chlorophenols, etc., and (ii) with the increase in the addition amount of urea $(0.050 \%)$, more urea molecules and their decomposition products can inhibit the activity of the catalyst that catalyzes the formation of PCDD/Fs and reduce the number of $\mathrm{Cl}$ ions, thereby inhibiting the de novo synthesis of PCDD/Fs (Ruokojärvi et al., 2004).

\section{Different Inhibition Behavior of PCDD/Fs Congeners Distribution of PCDD/Fs Congeners}

The PCDFs congeners emission concentration and their homologous profiles of 2,3,7,8-substituted PCDFs were showed in Fig. 4. As shown in the figure, the emission concentration of PeCDFs and HxCDFs occupied the dominant position of PCDFs emission in all samples. Compared with the non-urea test, the emission I-TEQ values of $\mathrm{HxCDFs}$ reduced from $0.179 \mathrm{ng}$ I-TEQ $\mathrm{Nm}^{-3}$ to 0.060 ,

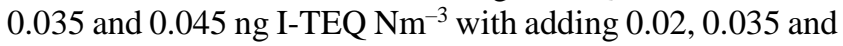
$0.05 \%$ urea. The corresponding distribution proportions dropped from $47.1 \%$ to $36.0,36.1$ and $34.1 \%$. The HpCDFs and OCDF emission concentrations and distribution ratios 

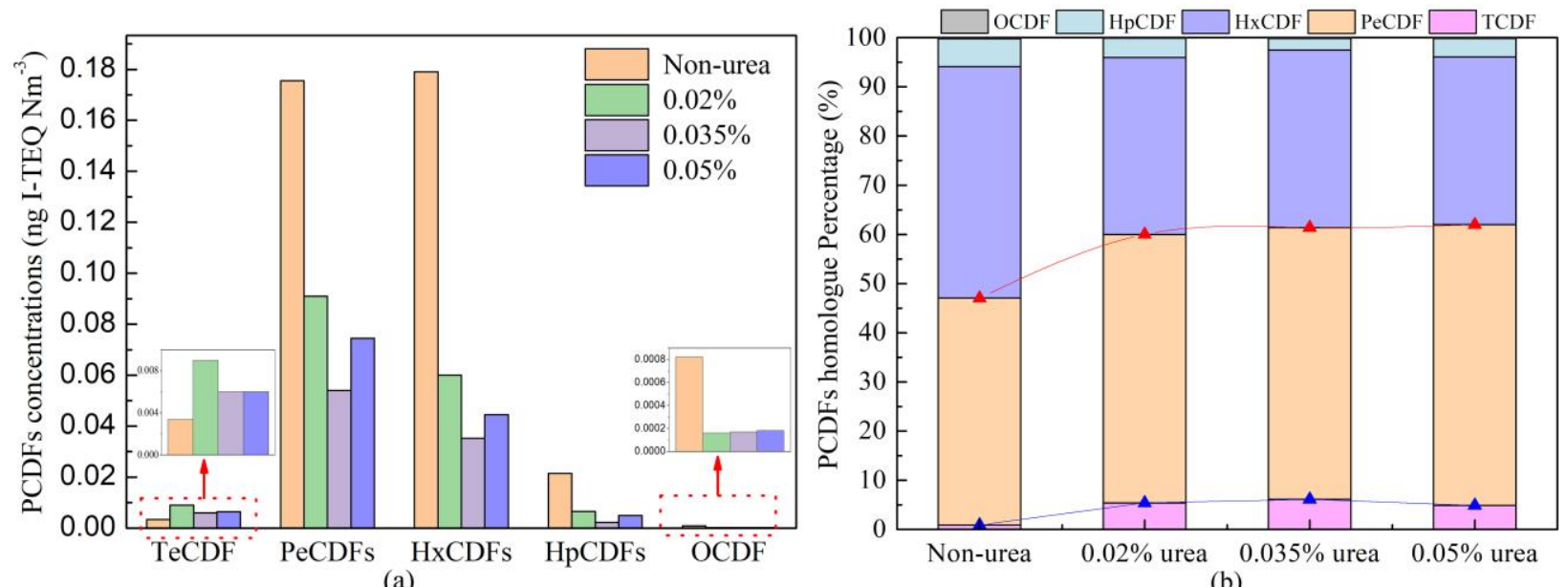

Fig. 4. PCDFs congeners emission concentration and distribution proportions of the 2,3,7,8-substituted PCDFs: (a) I-TEQ values of PCDFs congeners emission concentration; (b) PCDFs fingerprint.

were also significantly decreased. For PeCDFs, the emission

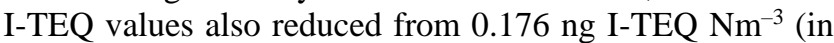
non-urea test) to $0.091,0.054$ and $0.075 \mathrm{ng} \mathrm{I}^{-T E Q ~} \mathrm{Nm}^{-3}$, while their distribution ratios have increased. Nevertheless, the emission I-TEQ values of low-chlorinated TeCDF increased from $0.003 \mathrm{ng} \mathrm{I-TEQ} \mathrm{Nm}^{-3}$ (in non-urea test) to $0.009,0.006$ and $0.006 \mathrm{ng}^{\mathrm{I}-\mathrm{TEQ} \mathrm{Nm}^{-3}}$ respectively, and the distribution ratios also augmented from $0.89 \%$ to $5.4,6.1$ and $4.9 \%$. These results were similar to the previous study on inhibition congeners of PCDD/Fs from fly ash by the addition of urea (Yan et al., 2013).

The effectual trend of urea on the emission concentrations and the congener profiles of 2,3,7,8-substituted PCDDs were the same as that of PCDFs, as shown in Fig. 5. The PeCDD and HxCDDs were the dominant congeners and the emissions of I-TEQ values were 0.045 and $0.048 \mathrm{ng} \mathrm{I-TEQ} \mathrm{Nm}^{-3}$ in the non-urea test. The emission of I-TEQ values and distribution proportions of PeCDD, HxCDDs, HpCDD, and OCDD were significantly decreased after adding urea. Among them, the percentages of PeCDD reduced from $37.3 \%$ to $26.7,18.8$

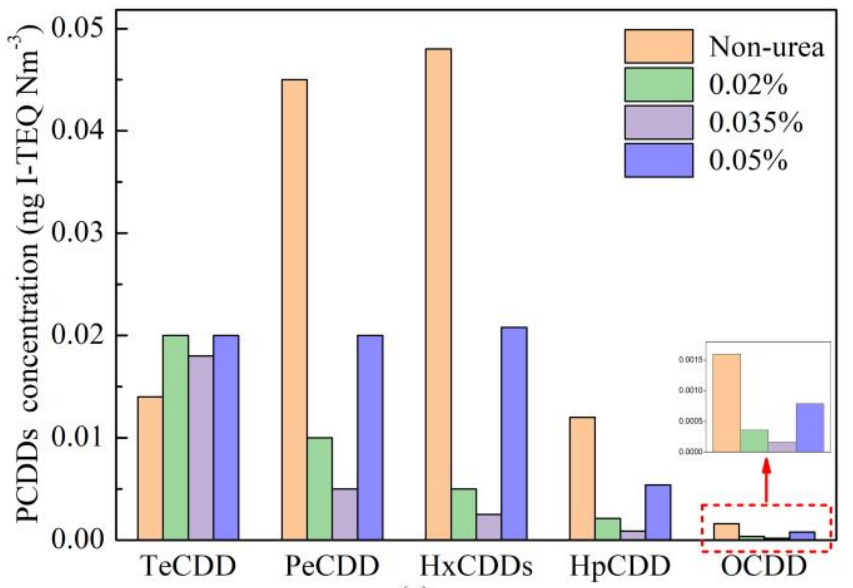

(a) and $29.9 \%$ and HxCDDs declined from $39.8 \%$ to $13.3,9.4$ and $31.0 \%$. However, emission concentration and distribution proportions of low-chlorinated TeCDD have increased. The I-TEQ values increased from $0.014 \mathrm{ng}$ I-TEQ $\mathrm{Nm}^{-3}$ (in the

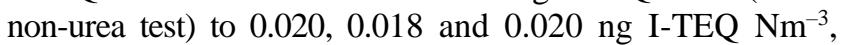
respectively, and their distribution proportions augmented from $11.6 \%$ to $53.4,67.8$ and $29.9 \%$. The distribution proportions occupied the dominant position of PCDDs.

\section{Differences in Inhibition of PCDD/Fs Congeners}

The inhibitory efficiencies of urea on PCDDs and PCDFs congeners were compared in Figs. 6(a) and 6(c), in which the inhibitory efficiencies on the low-chlorinated TeCDF and TeCDD were negative, while, in contrast, the inhibitory efficiencies for other congeners were above 50\%. This phenomenon can be inferred that the urea or its decomposition products promoted the dechlorination reaction of highchlorinated PCDFs or PCDDs, which resulted in the formation of TeCDF and PeCDFs so that the distribution proportions were significantly increased. Moreover, compared with the

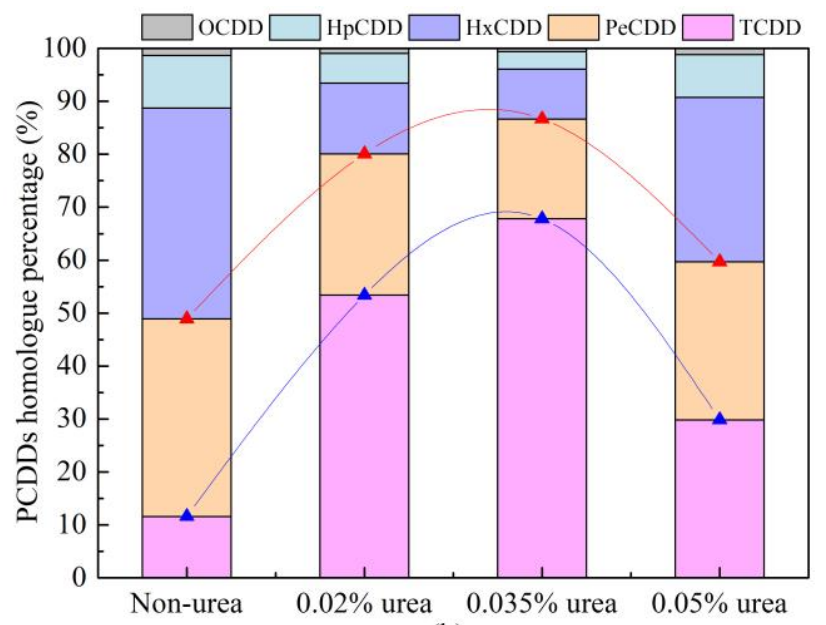

(b)

Fig. 5. PCDDs congeners emission concentration and distribution proportions of the 2,3,7,8-substituted PCDDs: (a) I-TEQ values of PCDDs congeners emission concentration; (b) PCDDs fingerprint. 


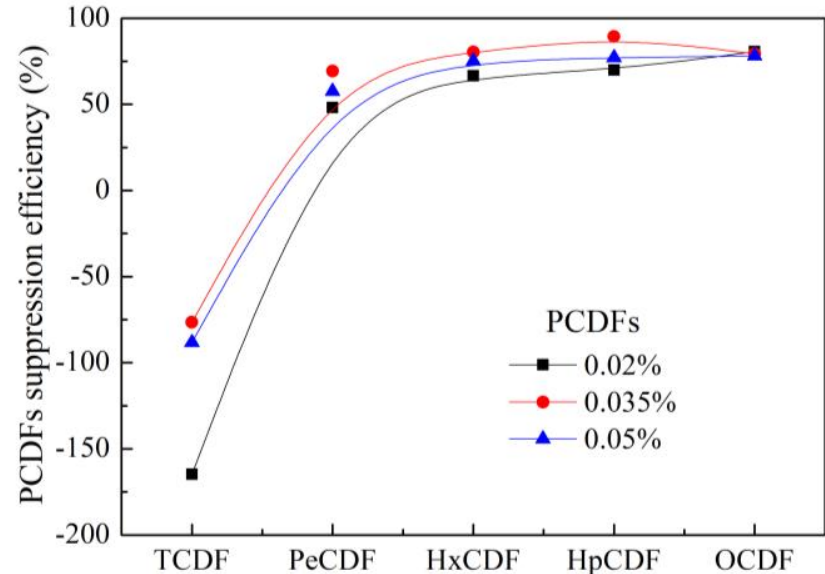

(a)

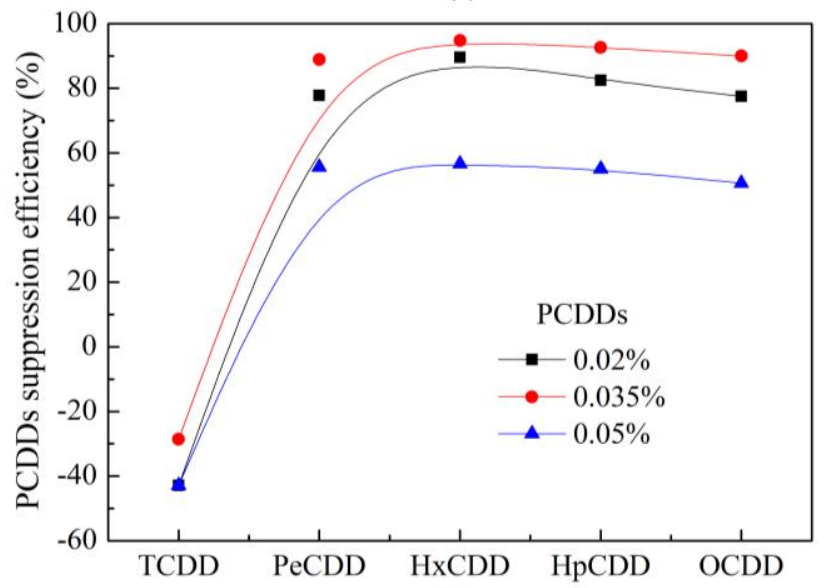

(c)

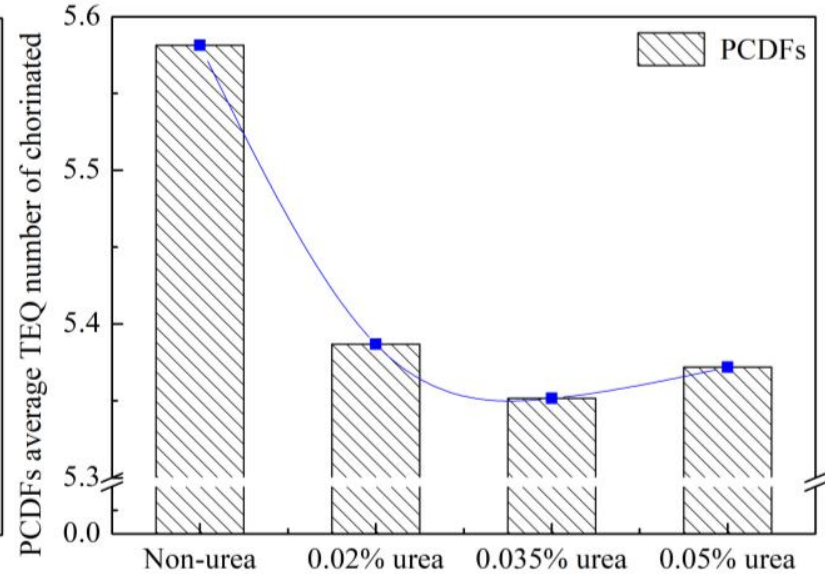

(b)

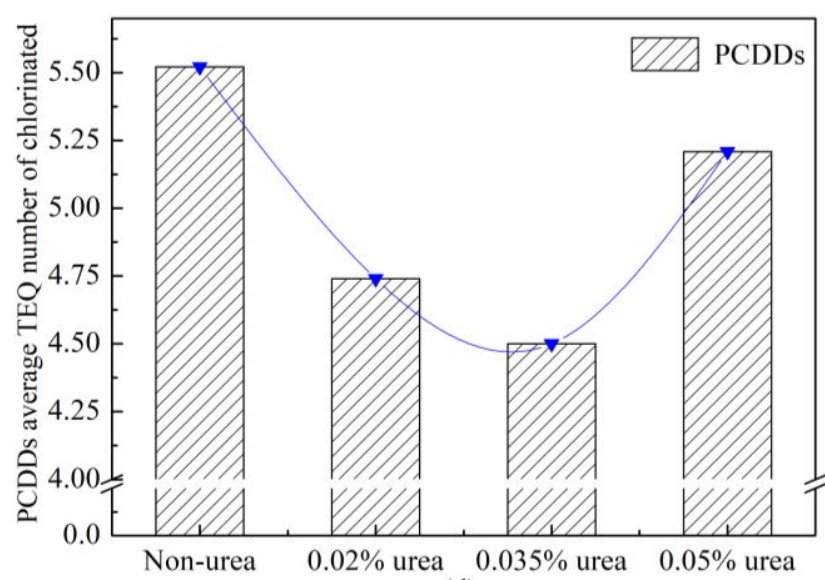

(d)

Fig. 6. The efficiency of PCDDs and PCDFs congeners suppression and average I-TEQ number of chlorine substituents after adding urea: (a) the efficiency of PCDFs congeners suppression; (b) the average I-TEQ number of chlorine substituents of PCDFs congeners; (c) the efficiency of PCDDs congeners suppression; (d) the average I-TEQ number of chlorine substituents of PCDDs congeners.

non-urea test, the average I-TEQ number of chlorine substituents of PCDFs and PCDDs decreased after the addition of urea, indicating that the chlorination process of PCDD/Fs was inhibited by urea, as shown in Figs. 6(b) and 6(d). To conclude, the dechlorination reaction might be a possible reason for the decrease in the average I-TEQ number of chlorine substituents.

\section{Inhibition Mechanisms}

Reduction Emission Mechanism of PCDD/Fs

The inhibition mechanisms of urea have investigated in our previous reports (Long et al., 2011; Qian et al., 2018). The mechanisms can be summed up into three aspects: (1) The passivation of $\mathrm{Cu}^{+}$, (2) the decrease of $\mathrm{Cl}_{2}$ amount, and (3) active radicals impede the formation of PCDD/Fs or attack the molecular bonds of PCDD/Fs. For the first mechanism, it is identified that the urea reacted with $\mathrm{Cu}^{+}$to generate some stable complexes, such as [urea-Cu] ${ }^{+}$or $\left[(\text { urea })_{2}-\mathrm{Cu}\right]^{+}$, thereby weakening the activity of metal catalysis (Luna et al., 2000). For the second mechanism, the $\mathrm{NH}_{3}$ formed by urea can react with $\mathrm{Cl}_{2}$ through Reaction (1) (Long et al., 2011). The $\mathrm{NH}_{3}$ can also react with $\mathrm{HCl}$ through
Reaction (2). The decrease of $\mathrm{HCl}$ concentration is beneficial to suppress the Deacon reaction (Eq. (3)) (Chen et al., 2019), thereby inhibiting the generation of $\mathrm{Cl}_{2}$. A decrease in the amount of $\mathrm{Cl}_{2}$ will significantly affect the de novo synthesis.

Urea can be decomposed at $135^{\circ} \mathrm{C}$ through Reactions (4)(7) and the effective decomposition reaches $100 \%$ at $600^{\circ} \mathrm{C}$ (Guerriero et al., 2009; Okamoto, 1999). Reactions (4)-(6) shows that the active radicals, including $\mathrm{N}$-containing active group $\left(\mathrm{NH}_{2} \cdot\right)$ and hydrogen radical $(\mathrm{H} \cdot)$, are formed during the urea pyrolysis process (Chen and Isa, 1998; Koebel and Strutz, 2003). Therefore, the third mechanism is that the active edge sites on the surface of the fly ash can be replaced by the $\mathrm{N}$-containing active group $\left(\mathrm{NH}_{2} \cdot\right)$, which prevents the generation of PCDD/Fs, as shown in Fig. 7. Meanwhile, the $\mathrm{C}-\mathrm{O}$ bond on the PCDD/Fs molecules can be attacked by hydrogen radical $(\mathrm{H} \cdot)$, then the $\mathrm{C}-\mathrm{O}$ bond is broken to form polychlorinated biphenyl or Polystream (Okamoto, 1999), as shown in Fig. 8.

$8 \mathrm{NH}_{3}+3 \mathrm{Cl}_{2} \rightarrow 6 \mathrm{NH}_{4} \mathrm{Cl}+\mathrm{N}_{2}$

$\mathrm{NH}_{3}+\mathrm{HCl} \rightarrow \mathrm{NH}_{4} \mathrm{Cl}$ 


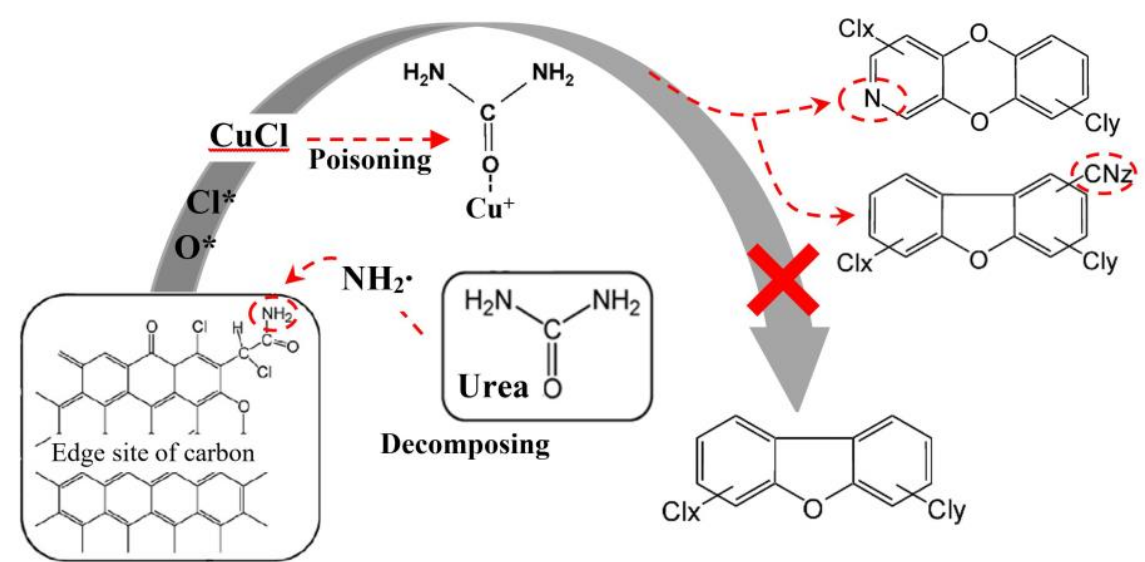

Fig. 7. Schematic diagram of active group $\left(\mathrm{NH}_{2} \cdot\right)$ inhibited the formation of PCDD/Fs.

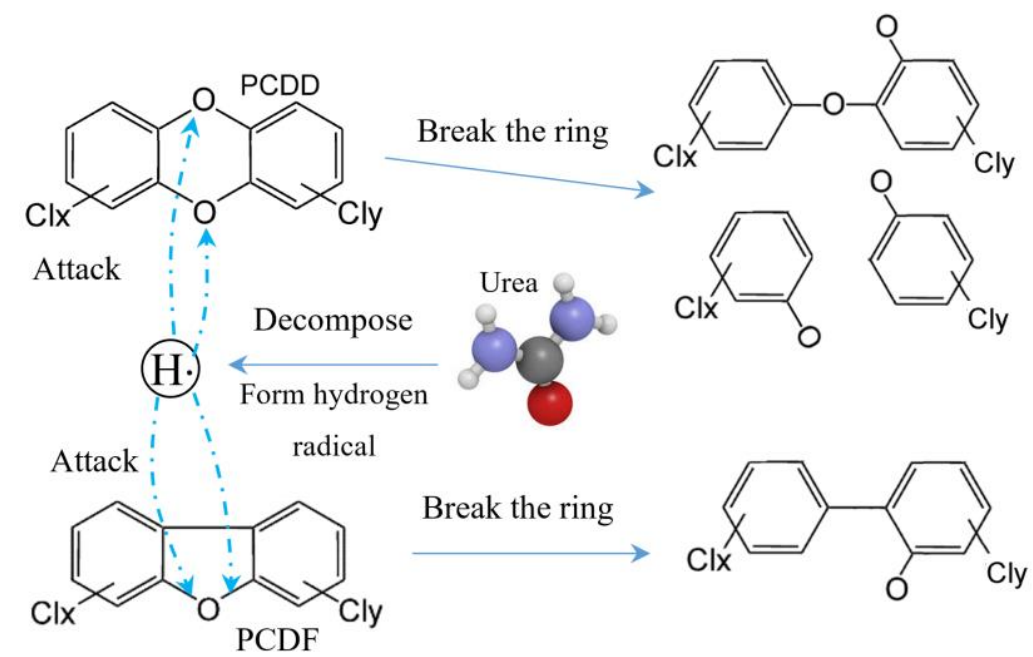

Fig. 8. Schematic diagram of the hydrogen radical $(\mathrm{H} \cdot)$ attacked $\mathrm{C}-\mathrm{O}$ bond on PCDD/Fs molecular.

$$
\begin{aligned}
& 4 \mathrm{HCl}+\mathrm{O}_{2} \rightarrow 2 \mathrm{Cl}_{2}+\mathrm{H} 2 \mathrm{O} \\
& \mathrm{CO}\left(\mathrm{NH}_{2}\right)_{2} \rightarrow\left(\mathrm{NH}_{2} \cdot\right)+(\mathrm{H} \cdot)+\mathrm{HNCO} \\
& \mathrm{H}_{2} \mathrm{NCO} \rightarrow(\mathrm{H} \cdot)+\mathrm{HNCO} \cdot \\
& \mathrm{HNCO} \rightarrow(\mathrm{H} \cdot)+\mathrm{NCO} \cdot \\
& \left(\mathrm{NH}_{2} \cdot\right)+(\mathrm{H} \cdot) \rightarrow \mathrm{HN}_{3}
\end{aligned}
$$

In addition, the remaining $\mathrm{NH}_{3}$ can be enriched in the over-wet layer and react with $\mathrm{SO}_{2}$ through Reactions (8-9). In this work, after adding urea, the desulfurization efficiencies were 56.3 (0.02\% urea), $58.0(0.035 \%$ urea) and $56.4 \%$ (0.05\% urea), respectively.

$$
\begin{aligned}
& 2 \mathrm{NH}_{3}+\mathrm{H}_{2} \mathrm{O}+\mathrm{SO}_{2}+1 / 2 \mathrm{O}_{2}=\left(\mathrm{NH}_{4}\right)_{2} \mathrm{SO}_{4} \\
& \mathrm{NH}_{3}+\mathrm{H}_{2} \mathrm{O}(\mathrm{g})+\mathrm{SO}_{2}+1 / 2 \mathrm{O}_{2}=\mathrm{NH}_{4} \mathrm{HSO}_{4}
\end{aligned}
$$

\section{Mechanism of Dechlorination Reaction}

The hydrogen radical generated directly in the pyrolysis process of urea has a strong activity, $\mathrm{H}$ - can attack the $\mathrm{C}-\mathrm{Cl}$ bond in the polychorinated biphenyl molecules to promote the hydrodechlorination reaction (Fueno et al., 2002; Altarawneh et al., 2009). The molecular structures of PCDD/Fs include $\mathrm{C}=\mathrm{C}$ bond, $\mathrm{C}-\mathrm{C}$ bond, $\mathrm{C}-\mathrm{H}$ bond, $\mathrm{C}-\mathrm{Cl}$ bond and $\mathrm{C}-\mathrm{O}$ bond, and their bond energies are showed in Fig. 9. Among them, the energy of the $\mathrm{C}=\mathrm{C}$ bond is the highest $\left(611 \mathrm{~kJ} \mathrm{~mol}^{-1}\right)$, while the $\mathrm{C}-\mathrm{Cl}$ bond is the lowest $\left(326 \mathrm{~kJ} \mathrm{~mol}^{-1}\right)$ (Qian et al., 2004; Altarawneh et al., 2009). Therefore, when the PCDD/Fs molecules are attacked by $\mathrm{H} \cdot, \mathrm{C}-\mathrm{Cl}$ bonds will be easier to break than other bonds.

Studies indicated that there are many chlorine atoms in the benzene ring of high-chlorinated PCDD/Fs, causing the increase of steric hindrance and weakening the interaction between $\mathrm{C}$ and $\mathrm{Cl}$ atoms so that the $\mathrm{C}-\mathrm{Cl}$ bond is vulnerable by the hydrogen radical (Zhang et al., 2004; Yang et al., 2006). In addition, a previous study (Lu et al., 2010) suggested that the chlorine atoms in the longitudinal $(1,4,6,9)$ positions are preferentially removed than the chlorine atoms on lateral $(2,3,7,8)$ positions. However, the $\mathrm{Cl}$ atoms of low-chlorinated $\mathrm{PCDD} / \mathrm{Fs}$ are mainly distributed in lateral positions among the 17 congeners of PCDD/Fs, so it is difficult for lowchlorinated $\mathrm{PCDD} / \mathrm{Fs}$ to dechlorinate the $\mathrm{Cl}$ atoms. In comparison, the chlorine atom numbers of high-chlorinated 


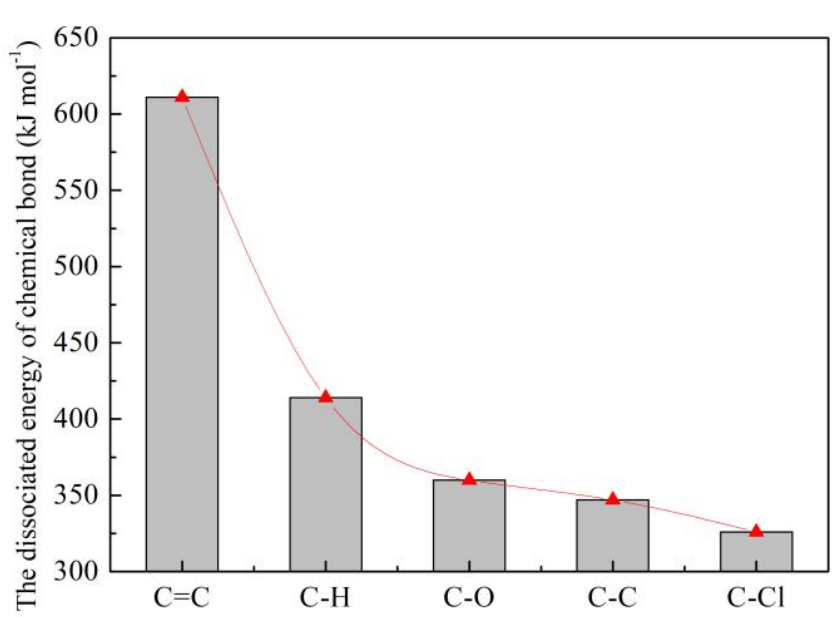

Fig. 9. The dissociated energy of the chemical bond of PCDD/Fs.

PCDD/Fs are more significant than that of low-chlorinated PCDD/Fs in longitudinal positions. Therefore, the longitudinal chlorine atoms of high-chlorinated PCDD/Fs are easy to remove by the hydrodechlorination reaction under the attack of hydrogen radical. Then the high-chlorinated PCDD/Fs was continuously converted to low-chlorinated PCDD/Fs after gradual dechlorination. The above demonstrated why urea had a more obvious inhibitory efficiency on high-chlorinated than that of low-chlorinated and the concentrations of TeCDD and TeCDF were increased after the addition of urea into the iron ore sintering mixture. Taking the highchlorinated OCDD and OCDF as examples, a dechlorination reaction occurred when the hydrogen radical attacks $\mathrm{Cl}$ atom of PCDD/Fs, as shown in Fig. 10. Therefore, based on the results that the addition of urea reduced the average I-TEQ number of chlorine substituents, it was suggested that the hydrodechlorination reaction might be the main mechanism for the increase of low-chlorinated PCDD/Fs.

\section{CONCLUSIONS}

In this study, urea was selected as an inhibitor to reduce the emission of PCDD/Fs during iron ore sintering. The I-TEQ values for the PCDD/Fs were evaluated, and the inhibition mechanisms were identified. The following conclusions were drawn:

(1) After adding 0.02-0.05 wt.\% urea particles into the iron ore sintering mixture, the I-TEQ values for the total PCDD/Fs were reduced by $60.0-76.0 \%$, and the average I-TEQ value for the chlorine substituents decreased, indicating that urea inhibits the chlorination of PCDD/Fs.

(2) The mechanisms driving the reduction in PCDD/F emission can be divided into three categories: (i) the poisoning of $\mathrm{Cu}^{+}$; (ii) the decrease in $\mathrm{Cl}_{2}$ and (iii) the effect of active radicals, which impede the formation or weaken the molecular bonds of PCDD/Fs.

(3) With the incorporation of urea, the I-TEQ values for the emitted high-chlorinated PCDD/Fs decreased sharply, whereas those for the low-chlorinated ones rose, suggesting that the hydrodechlorination reaction may be the primary mechanism driving the increase in lowchlorinated PCDD/Fs.

\section{ACKNOWLEDGMENTS}

This work was supported by the Key Program of National Natural Science Foundation of China (U1660206 and 51674002). One of the authors (L.X. Qian) also acknowledges the scholarship offered by the China Scholarship Council (CSC) via the Joint-Training Ph.D. Program (Grant No. 201908340086).

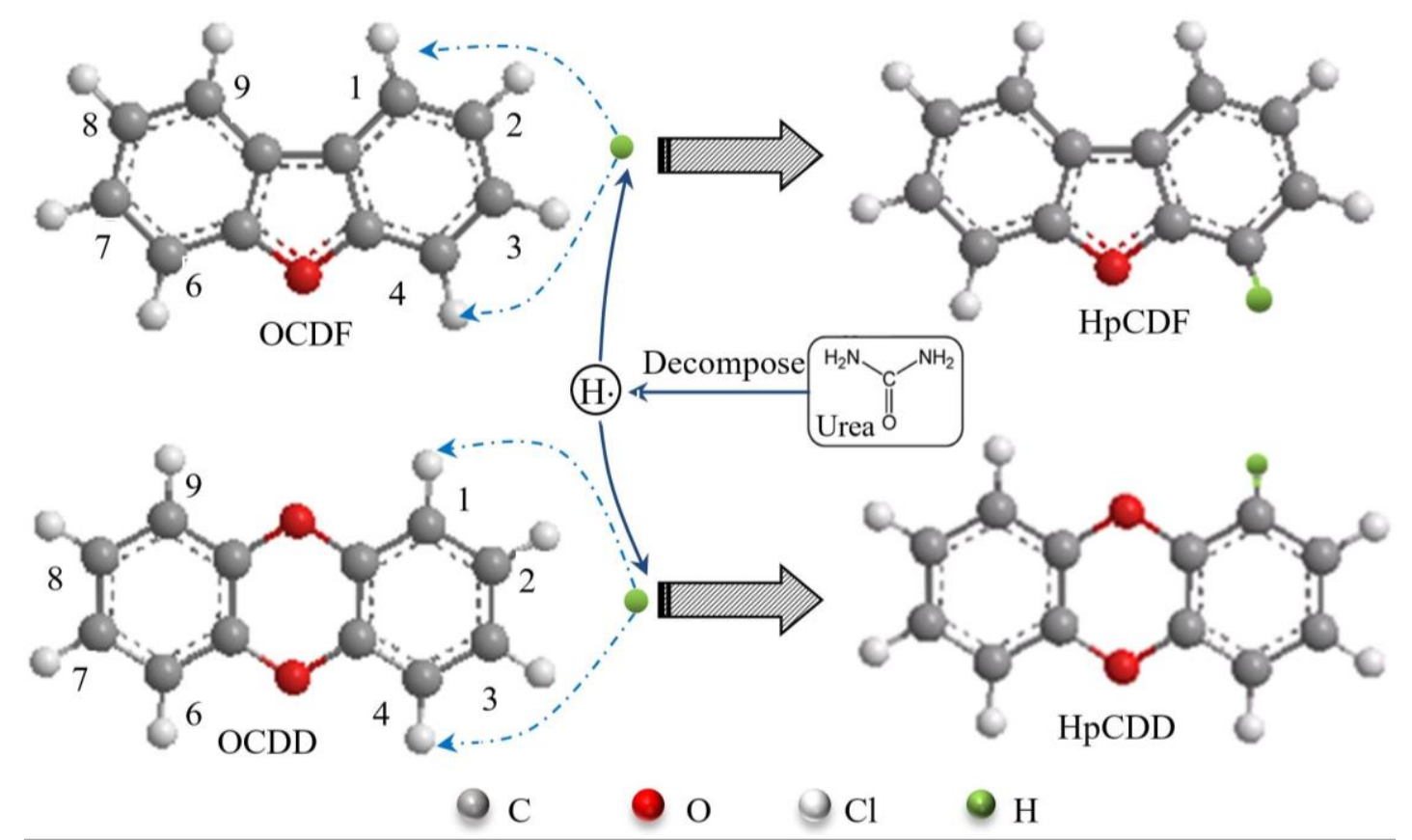

Fig. 10. Schematic diagram of hydrogen radical $(\mathrm{H} \cdot)$ attacked $\mathrm{Cl}$ atoms on PCDD/Fs molecular. 


\section{REFERENCES}

Abreu, G.C., de Carvalho, Jr., J.A., de Silva, B.E.C. and Pedrini, R.H. (2015). Operational and environmental assessment on the use of charcoal in iron ore sinter production. J. Cleaner Prod. 101: 387-394. https://doi.org/ 10.1016/j.jclepro.2015.04.015

Altarawneh, M., Dlugogorski, B.Z., Kennedy, E.M. and Mackie, J.C. (2009). Mechanisms for formation, chlorination, dechlorination and destruction of polychlorinated dibenzo- $p$-dioxins and dibenzofurans (PCDD/Fs). Prog. Energy Combust. 35: 245-274. https://doi.org/10.1016/j.pecs.2008.12.001

Anderson, D.R., Fisher, R., Johnston, S., Aries, E., Fray, T.A. and Ooi, T.C. (2007). Investigation into the effect of organic nitrogen compounds on the suppression of $\mathrm{PCDD} / \mathrm{Fs}$ in iron ore sintering. Organohalogen Compd. 69: 2470-2473.

Chen, J.P. and Isa, K. (1998). Thermal decomposition of urea and urea derivatives by simultaneous TG/(DTA)/MS. $J$. Mass Spectrom. Soc. Jpn. 46: 299-303. https://doi.org/10. 5702/massspec.46.299

Chen, S.D., Cui, K.P., Zhao, Y.X., Yin, Z.M., Chao, H.R. and Chang-Chien, G.P. (2018). Sensitivity analysis of atmospheric $\mathrm{PM}_{2.5}$-bound content and dry deposition of total PCDD/Fs-TEQ: In the case of Xiamen and Zhangzhou, China. Aerosol Air Qual. Res. 18: 3096-3114. https://doi.org/10.4209/aaqr.2018.11.0393

Chen, Y.C., Kuo, Y.C., Chen, M.R., Wang, Y.F., Chen, C.H., Lin, M.Y., Yoon, C. and Tsai, P.J. (2016). Reducing polychlorinated dibenzo- $p$-dioxins and dibenzofurans (PCDD/F) emissions from a real-scale iron ore sinter plant by adjusting its sinter raw mix. J. Cleaner Prod. 112: 1184-1189. https://doi.org/10.1016/j.jclepro.2015.07.013

Chen, Z.L., Lin, X.Q., Lu, S.Y., Li, X.D. and Yan, J.H. (2019). Suppressing formation pathway of PCDD/Fs by $\mathrm{S}-\mathrm{N}$-containing compound in full-scale municipal solid waste incinerators. Chem. Eng. J. 359: 1391-1399. https://doi.org/10.1016/j.cej.2018.11.039

Cheng, Z.L., Wei, S.S., Guo, Z.G., Yang, J. and Wang, Q.W. (2017). Improvement of heat pattern and sinter strength at high charcoal proportion by applying ultra-lean gaseous fuel injection in iron ore sintering process. J. Cleaner Prod. 161: 1374-1384. https://doi.org/10.1016/j.jclepro.2017.07.017

Chun, T.J., Long, H.M., Di, Z.X., Zhang, X.Y., Wu, X.J. and Qian, L.X. (2017). Novel technology of reducing $\mathrm{SO}_{2}$ emission in the iron ore sintering. Process Saf. Environ. Prot. 105: 297-302. https://doi.org/10.1016/j.psep.2016. 11.012

Drage, D.S., Aries, E. and Harrad, S. (2014). Studies into the formation of PBDEs and PBDD/Fs in the iron ore sintering process. Sci. Total Environ. 485-486: 497-507. https://doi.org/10.1016/j.scitotenv.2014.03.093

Dvořák, R., Chlápek, P., Jecha, D., Puchýř, R. and Stehlík, P. (2010). New approach to common removal of dioxins and $\mathrm{NO}_{\mathrm{x}}$ as a contribution to environmental protection. $J$. Cleaner Prod. 18: 881-888. https://doi.org/10.1016/j.jcle pro.2010.01.024

Fueno, H., Tanaka, K. and Sugawa, S. (2002). Theoretical study of the dechlorination reaction pathways of octachlorodibenzo-p-dioxin. Chemosphere 48: 771-778. https://doi.org/10.1016/s0045-6535(02)00141-8

Guerriero, E., Bianchini, M., Gigliucci, P.F., Guarnieri, A., Mosca, S., Rossetti, G., Varde, M. and Rotatori, M. (2009). Influence of process changes on PCDD/Fs produced in an iron ore sintering plant. Environ. Eng. Sci. 26: 71-80. https://doi.org/10.1089/ees.2007.0053

Harjanto, S., Kasai, E., Terui, T. and Nakamura, T. (2002). Behavior of dioxin during thermal remediation in the zone combustion process. Chemosphere 47: 687-693. https://doi.org/10.1016/S0045-6535(02)00012-7

Huang, H. and Buekens, A. (1995). On the mechanisms of dioxin formation in combustion processes. Chemosphere 31: 4099-4117. https://doi.org/10.1016/0045-6535(95)80 $011-9$

Ji, Z.Y., Gan, M., Fan, X. H., Chen, X.L., Li, Q., Lv, W., Tian, Y., Zhou, Y. and Jiang, T. (2017). Characteristics of $\mathrm{PM}_{2.5}$ from iron ore sintering process: Influences of raw materials and controlling methods. J. Cleaner Prod. 148: 12-22. https://doi.org/10.1016/j.jclepro.2017.01.103

Jiang, T., Yu, Z.W., Peng, Z.W., Rao, M.J., Zhang, Y.B. and Li, G.H. (2015). Preparation of BF burden from titanomagnetite concentrate by composite agglomeration process (CAP). ISIJ Int. 55: 1599-1607. https://doi.org/10. 2355/isijinternational.ISIJINT-2015-094

Kasai, E., Kuzuhara, S., Goto, H. and Murakami, T. (2008). Reduction in dioxin emission by the addition of urea as aqueous solution to high-temperature combustion gas. ISIJ Int. 48: 1305-1310. https://doi.org/10.2355/isijintern ational.48.1305

Koebel, M. and Strutz, E.O. (2003). Thermal and hydrolytic decomposition of urea for automotive selective catalytic reduction systems: thermochemical and practical aspects. Ind. Eng. Chem. Res. 42: 2093-2100. https://doi.org/10.1 021/ie020950o

Kumar, T.K.S., Simonsson, M., Viswanathan, N.N., Ahmed, H., Andersson, C., El Geassy, A.H.A. and Björkman, B. (2018). Establishing a novel methodology to correlate the macroscopic and microscopic degree of sintering in magnetite pellets during induration. Steel Res. Int. 89: 1700366. https://doi.org/10.1002/srin.201700366

Kuo, Y.C., Chen, Y.C., Yang, C.W., Mou, J.L., Shih, T.S. and Tsai, P.J. (2011). Identification the content of the windbox dust related to the formation of PCDD/Fs during the iron ore sintering process. Aerosol Air Qual. Res. 11: 351-359. https://doi.org/10.4209/aaqr.2011.03.0024

Kuo, Y.C., Chen, Y.C., Yang, J.H., Tsai, P.J., Wang, L.C. and Chang-Chien, G.P. (2012). Correcting the gas and particle partitioning of PCDD/F congeners in the flue gas of an iron ore sinter plant. J. Hazard. Mater. 209-210: 402-407. https://doi.org/10.1016/j.jhazmat.2012.01.045

Li, J.F., Zhang, Y., Sun, T.T., Hao, H.W., Wu, H., Wang, L.L., Chen, Y.X., Xing, L.M. and Niu, Z.G. (2018). The health risk levels of different age groups of residents living in the vicinity of municipal solid waste incinerator posed by PCDD/Fs in atmosphere and soil. Sci. Total Environ. 631-632: 81-91. https://doi.org/10.1016/j.scitot env.2018.03.009 
Liao, J.H., Buekens, A., Olie, K., Yang, J., Chen, T. and Li, X.D. (2016). Iron and copper catalysis of PCDD/F formation. Environ. Sci. Pollut. Res. 23: 2415-2425. https://doi.org/10.1007/s11356-015-5437-Z

Liu, X.L., Ye, M., Wang, X., Liu, W. and Zhu, T.Y. (2017). Gas-phase and particle-phase PCDD/F congener distributions in the flue gas from an iron ore sintering plant. J. Environ. Sci.-China 54: 239-245. https://doi.org/ 10.1016/j.jes.2016.01.023

Long, H.M., Li, J.X., Wang, P., Gao, G. and Tang, G.W. (2011). Emission reduction of dioxin in iron ore sintering by adding urea as inhibitor. Ironmaking Steelmaking 38: 258-262. https://doi.org/10.1179/1743281210Y.0000000 008

Lu, G.N., Dang, Z., Fennell, D.E., Huang, W., Li, Z. and Liu, C.Q. (2010). Rules of thumb for assessing reductive dechlorination pathways of PCDDs in specific systems. $J$. Hazard. Mater. 177: 1145-1149. https://doi.org/10.1016/ j.jhazmat.2009.12.051

Luna, A., Amekraz, B., Morizur, J.P., Tortajada, J., Mó, O. and Yanez, M. (2000). Reactions of urea with $\mathrm{Cu}^{+}$in the gas phase: An experimental and theoretical study. J. Phys. Chem. A 104: 3132-3141. https://doi.org/10.1021/jp9934 634

Ma, H.T., Du, N., Lin, X.Y., Liu, C.F., Zhang, J.Y. and Miao, Z.Z. (2018). Inhibition of element sulfur and calcium oxide on the formation of PCDD/Fs during co-combustion experiment of municipal solid waste. Sci. Total Environ. 633: 1263-1271. https://doi.org/10.1016/j.scitotenv.2018. 03.282

Ma, Y.F., Lin, X.Q., Chen, Z.L., Chen, T., Zhan, M.X., Xu, S.X., Wu, H.L., Li, X.D. and Yan, J.H. (2019). Emission characteristics and formation pathways of polychlorinated dibenzo- $p$-dioxins and dibenzofurans from a typical pesticide plant. Aerosol Air Qual. Res. 19: 1390-1399. https://doi.org/10.4209/aaqr.2019.04.0224

Nakano, M., Hosotani, Y. and Kasai, E. (2005). Observation of behavior of dioxins and some relating elements in iron ore sintering bed by quenching pot test. ISIJ Int. 45: 609617. https://doi.org/10.2355/isijinternational.45.609

Okamoto, Y. (1999). A new dioxin decomposition process based on a hybrid density-functional calculation. Chem. Phys. Lett. 310: 355-360. https://doi.org/10.1016/S00092614(99)00761-7

Ooi, T.C., Aries, E., Anderson, D.R., Fray, R. and Thompson, D. (2008a). Melamine as suppressant of PCDD/F formation in the sintering process. Organohalogen Compd. 70: 5861.

Ooi, T.C., Aries, E., Ewan, B.C.R., Thompson, D., Anderson, D.R., Fisher, R., Fray, T. and Tognarelli, D. (2008b). The study of sunflower seed husks as a fuel in the iron ore sintering process. Miner. Eng. 21: 167-177. https://doi.org/10.1016/j.mineng.2007.09.005

Peng, Y.Q., Chen, J.H., Lu, S.Y., Huang, J.X., Zhang, M.M., Buekens, A., Li, X.D. and Yan, J.H. (2016). Chlorophenols in municipal solid waste incineration: A review. Chem. Eng. J. 292: 398-414. https://doi.org/10.1016/j.cej.2016. 01.102

Qian, L.X., Long, H.M., Wu, X.J., Chun, T.J. and Wang,
Y.F. (2016). Detection of dioxin emitted during the iron ore sintering process. Environ. Pollut. Control 38: 34-38. Qian, L.X., Chun, T.J., Long, H.M., Li, J.X., Di, Z.X., Meng, Q.M. and Wang, P. (2018). Emission reduction research and development of PCDDFs in the iron sintering. Process Saf. Environ. Prot. 117: 82-91. https://doi.org/1 0.1016/j.psep.2018.04.014

Qian, Y.J., Wu, Z.S. and Li, F.J. (2004). Dioxins formation conditions and control measures in garbage incineration. China Environ. Prot. Ind. S1: 80-83.

Rezvanipour, H., Mostafavi, A., Ahmadi, A., Karimimobarakabadi, M. and Khezri, M. (2018). Desulfurization of iron ores: Processes and challenges. Steel Res. Int. 89: 1700568. https://doi.org/10.1002/srin.2 01700568

Ruokojärvi, P., Aatamila, M., Tuppurainen, K. and Ruuskanen, J. (2001). Effect of urea on fly ash PCDD/F concentrations in different particle sizes. Chemosphere 43: 757-762. https://doi.org/10.1016/S0045-6535(00)00430-6

Ruokojärvi, P.H., Asikainen, A.H., Tuppurainen, K.A. and Ruuskanen, J. (2004). Chemical inhibition of PCDD/F formation in incineration processes. Sci. Total Environ. 325: 83-94. https://doi.org/10.1016/j.scitotenv.2003.11.006

Shen, X., Chen, L.G., Xia, S.J., Xie, Z.H. and Qin, X.Y. (2018). Burdening proportion and new energy-saving technologies analysis and optimization for iron and steel production system. J. Cleaner Prod. 172: 2153-2166. https://doi.org/10.1016/j.jclepro.2017.11.204

Southern, S., Edmundson, J. and Hakimian, M. (2000). Environmental improvement from the sintering process. Proceedings $4^{\text {th }}$ European Coke and Ironmaking Congress, pp. 380-386.

Tang, H.Y., Cui, K.P., Xing, J., Zhu, J.N., Lee, W.J., Mwangi, J.K. and Lee, Y.C. (2017). Part I: PM $_{2.5}$ and polychlorinated dibenzo- $p$-dioxins and dibenzofurans (PCDD/Fs) in the ambient air of southern China. Aerosol Air Qual. Res. 17: 1550-1569. https://doi.org/10.4209/aa qr.2017.03.0117

Thompson, D., Ooi, T.C., Anderson, D.R., Fisher, R. and Bcr, E. (2016). The polychlorinated dibenzofuran fingerprint of iron ore sinter plant: Its persistence with suppressant and alternative fuel addition. Chemosphere 154: 138-147. https://doi.org/10.1016/j.chemosphere.2016.03.066

Van den Berg, M., Birnbaum, L.S., Denison, M., De Vito, M., Farland, W., Feeley, M., Fiedler, H., Hakansson, H., Hanberg, A. and Haws, L. (2006). The 2005 World Health Organization reevaluation of human and mammalian toxic equivalency factors for dioxins and dioxin-like compounds. Toxicol. Sci. 93: 223-241. https://doi.org/10. 1093/toxsci/kfl055

Weber, R. and Hagenmaier, H. (1999). PCDD/PCDF formation in fluidized bed incineration. Chemosphere 38 : 2643-2654. https://doi.org/10.1016/S0045-6535(98)004 $72-\mathrm{X}$

Wu, X.J., Long, H.M. and Chun, T.J. (2016). Emission reduction of $\mathrm{PCDD} / \mathrm{Fs}$ in iron ore sintering process by adding urea. Environ. Pollut. Control 38: 61-66.

Xhrouet, C. and Pauw, E.D. (2005). Formation of PCDD/Fs in the sintering process: Role of the grid- $\mathrm{Cr}_{2} \mathrm{O}_{3}$ catalyst in 
the de novo synthesis. Chemosphere 59: 1399-1406. https://doi.org/10.1016/j.chemosphere.2004.12.027

Xhrouet, C., Pirard, C. and De, P.E. (2001). De novo synthesis of polychlorinated dibenzo- $p$-dioxins and dibenzofurans on fly ash from a sintering process. Environ. Sci. Technol. 35: 1616-1623. https://doi.org/10.1021/es000199f

Xing, J., Cui, K.P., Tang, H.Y., Lee, W.J., Wang, L.C., Zhu, J.N. and Huang, Q.L. (2017). Part II: $\mathrm{PM}_{2.5}$ and polychlorinated dibenzo- $p$-dioxins and dibenzofurans (PCDD/Fs) in the ambient air of northern China. Aerosol Air Qual. Res. 17: 2010-2026. https://doi.org/10.4209/aa qr.2017.06.0211

Xu, P.W., Chen, Z.J., Wu, L.Z., Chen, Y., Xu, D.D., Shen, H.T., Han, J.L., Wang, X.F. and Lou, X.M. (2019). Health risk of childhood exposure to PCDD/Fs emitted from a municipal waste incinerator in Zhejiang, China. Sci. Total Environ. 689: 937-944. https://doi.org/10.1016/j.scitoten v.2019.06.425

Xuan, Z.Q., Bi, C.L., Li, J.F., Nie, J.H. and Chen, Z.H. (2017). Source contributions to total concentrations and carcinogenic potencies of polychlorinated dibenzo- $p$ dioxins and polychlorinated dibenzofurans (PCDD/Fs) in ambient air: A case study in Suzhou City, China. Environ. Sci. Pollut. Res. 24: 23966-23976. https://doi.org/10.100 7/s11356-017-0050-y

Yabar, H., Uwasu, M. and Hara, K. (2013). Tracking environmental innovations and policy regulations in Japan: Case studies on dioxin emissions and electric home appliances recycling. J. Cleaner Prod. 44: 152-158. https://doi.org/10.1016/j.jclepro.2012.10.045

Yan, M., Yang, J., Li, X.D., Hu, Y.J. and Yan, J.H. (2013). Inhibition of PCDD/Fs formation from fly ash by ammonium sulfate and urea. CIESC J. 64: 4196-4202.

Yan, M., Qi, Z.F., Yang, J., Li, X.D., Ren, J.L. and Xu, Z. (2014). Effect of ammonium sulfate and urea on PCDD/F formation from active carbon and possible mechanism of inhibition. J. Environ. Sci.-China 26: 2277-2282. https://doi.org/10.1016/j.jes.2014.09.012

Yang, L.L., Liu, G.R., Zheng, M.H., Jin, R., Zhu, Q.Q.,
Zhao, Y.Y., Zhang, X. and Xu, Y. (2017). Atmospheric occurrence and health risks of PCDD/Fs, polychlorinated biphenyls, and polychlorinated naphthalenes by air inhalation in metallurgical plants. Sci. Total Environ. 580: 1146-1154. https://doi.org/10.1016/j.scitotenv.2016.12.071

Yang, L.L., Zhao, Y.Y., Shi, M.W., Zheng, M.H., Xu, Y., Li, C., Yang, Y.P., Qin, L.J. and Liu, G.R. (2019). Brominated dioxins and furans in a cement kiln coprocessing municipal solid waste. J. Environ. Sci.-China 79: 339-345.

Yang, Z.J., Xia, C.H., Zhang, Q., Chen, J.P., Wu, W.Z., Liang, X.M. and Kettrup, A. (2006). Treatment of PCDD/Fs and PCBs in fly ash extracts under mild conditions. Fresenius Environ. Bull. 15: 86-94.

Yu, M.F., Lin, X.Q., Yan, M., Li, X.D., Chen, T. and Yan, J.H. (2016). Low temperature destruction of PCDD/Fs over $\mathrm{V}_{2} \mathrm{O}_{5}-\mathrm{CeO}_{2} / \mathrm{TiO}_{2}$ catalyst with ozone. Environ. Sci. Pollut. Res. 23: 17563-17570. https://doi.org/10.1007/s1 1356-016-6955-Z

Zhan, M.X., Ma, Y.F., Lin, X.Q., Chen, Z.L., Chen, T., Li, X.D. and Yan, J.H. (2019). PCDD/F emission from pharmaceutical industries. Aerosol Air Qual. Res. 19: 2070-2082. https://doi.org/10.4209/aaqr.2019.06.0284

Zhang, Q., Liang, X.M., Xu, J., Chen, J.P. and Lu, P.Z. (2004). Chemical dechlorination of PCB in transformer oil by use of nano-NaH and its assessment. Fine Chemicals 7: 540-543.

Zhang, Y.B., Liu, L.N., Sun, Y.F., Zhu, R., Gao, X.B., Yang, J.L., Han, Z.Q. and Wang, H. (2016). Formation of persistent chlorinated aromatic compounds in simulated and real fly ash from iron ore sintering. J. Mater. Cycles Waste Manage. 19: 1437-1445. https://doi.org/10.1007/s 10163-016-0537-5

Received for review, February 3, 2020

Revised, May 13, 2020

Accepted, May 15, 2020 